\title{
Ф.В. Грушин
}

\section{ФАКТОРНЫЙ ПОДХОД В ОТРАСЛЕВЫХ ЮРИДИЧЕСКИХ НАУКАХ}

\begin{abstract}
В статье рассматриваются различные точки зрения на проблемы факторного подхода в теории права и в таких отраслевых юридических науках, как уголовное и гражданское право.

Ключевые слова: факторный подход, сущнность права, система права, правотворчество, детерминирующие факторы, эффективность правотворчества.
\end{abstract}

В настоящее время одним из актуальных вопросов как в теории права, так и в отраслевых юридических науках является вопрос анализа всевозможных причин и условий, определяющих развитие и функционирование системы права. Применяя факторный подход к оценке правовых явлений, возможно выявить сущность права, повысить эффективность правотворчества и в конечном счете реализации правовых норм.

Факторный подход в гораздо большей степени анализируется в трудах ученых по философии и общей теории права. В то же время идеи детерминизма все чаще звучат и в отраслевых юридических науках, поскольку исследование системы отрасли права на этой методологической основе способствует познанию ее внутреннего содержания, образующих ее структурных элементов, их взаимосвязи и взаимозависимости, выявлению внутренних противоречий и, следовательно, созданию условий для эффективной модернизации конкретной отрасли права. Однако сложность исследования детерминации в правовой области социальной жизни, зачастую объясняемая наличием огромного числа детерминирующих факторов, обусловила отсутствие единообразия в использовании факторного подхода в юридической науке, несмотря на то, что, как отмечает В.И. Овчинников, проблема детерминизма по своему характеру, объему, содержанию и методологическому значению является фундаментальной для правоведения [1. С. 38].

Ситуация осложняется и пониманием того, что «отношения между правом и факторами, его обусловливающими, - это не параллельные и независимые отношения, а цепь взаимосвязанных отношений, в рамках которых материальные факторы, являющиеся в конечном итоге определяющими, от ступени к ступени детерминируют элементы будущих правовых норм через посредство факторов духовных» [2. С. 15]. И если между экономикой и правом возможно установление причинно-следственных связей, то при изучении особенностей влияния на него иных факторов категории причины и следствия оказываются неприменимыми, поскольку их существование скорее следует рассматривать как условия правообразования и правореализации, которые могут влиять на них с разной степенью интенсивности. Так, Д.Б. Беспрозванный выделяет среди непричинных типов детерминации кон- 
дициональную (условную), функциональную, инспирирующую, системную детерминацию и корреляцию [3. С. 141-143]. Первая ставит различные явления в зависимость от определенных условий, которые оказывают порой более серьезное влияние, чем причина. Функциональная детерминация означает, что ни один материальный процесс, в том числе процесс подготовки правовых предписаний, не происходит в абсолютной изоляции, а связан с параллельно протекающими процессами и зависит от них. Инспирирующая детерминация позволяет учитывать факторы, служащие поводом, «подталкивающие», запускающие те или иные процессы, направленные на необходимость разработки правовых предписаний. Системная детерминация позволяет рассматривать единое целое как отдельные части с их связями и взаимозависимостями, усовершенствовать (в нашем случае) различные виды правовых предписаний. Корреляционная детерминация вызывает необходимость изучения причин и условий, с которыми могут быть связаны изменения нормативно-правовых, правоприменительных, интерпретационных предписаний.

При этом нельзя не отметить принципиально различный подход к определению целей использования теории факторов в отраслевых науках. Так, А.А. Тер-Акопов, считая, что «вне категории детерминизма нельзя всерьез говорить ни о социологии уголовного права, ни об уголовной политике; нельзя понять и представить значение уголовного закона и основания его введения, сущность и роль уголовного наказания, механизм его применения» [4. С. 276], делает акцент на прикладном значении детерминизма, оценивая смысловую нагрузку отдельных законодательных формулировок (в частности, используемых в УК РФ терминов «повлечь» и «причинить»), выявляя систему детерминант преступного поведения и определяя их значение для построения системы уголовного права и квалификации конкретного деяния. При этом вопросы преступности и наказуемости деяний, определяемые многочисленными общественными факторами, остаются за пределами его исследования, несмотря на признание им того, что игнорирование детерминистического подхода, как это нередко имеет место в уголовно-правовой науке, обедняет научный арсенал, не позволяет представить изучаемое явление во всей его полноте, видеть скрытые процессы и закономерности, а значит, использовать их и воздействовать на них.

Одним из первых относительно системно факторный подход в науке уголовного права реализовал О.В. Гревцов, который выделил объективные и субъективные факторы формирования уголовной политики, одновременно признавая их факторами преступности. По его мнению, «факторы, определяющие преступность и уголовную политику, представляют собой диалектическое единство объективных условий и субъективных предпосылок общественного развития и включают политические, правовые и иные общественные отношения, естественные условия, правовую культуру... Генерируемые этими факторами социальные противоречия создают принципиальную возможность преступности, формирования и функционирования уголовной политики» [5. С. 83]. Однако такой подход вызывает некоторые сомнения, поскольку преступность и уголовная политика представляют собой абсолютно разные, хотя и находящиеся в сложном взаимодействии явления. Даже если рас- 
сматривать одни и те же факторы применительно к каждому из них, становится очевидно, что проявляют они себя по-разному.

Кроме того, вызывает возражения реализуемый им подход к самой системе факторов. Так, объективными факторами им признаются: исторический тип способа производства, производственных отношений, противоречия между производительными силами и производственными отношениями; политические отношения; правовые отношения и нормы; идеологические, морально-этические и иные социальные отношения; географические, демографические, наследственно-биологические и иные природные условия; правовая культура. Однако этот перечень скорее свидетельствует о нарушении базовых принципов построения любой системы, прежде всего отсутствии единого критерия для систематизации и различной степени конкретизации ее элементов. Та же проблема прослеживается и в оценке субъективных факторов, которыми признаются интересы, потребности субъектов уголовной политики и субъектов правоотношений; личностные качества, психические процессы, свойства, состояния и образования общественно-политических и государственных лидеров, субъектов правоотношений; политические решения и действия субъектов уголовной политики; общественное сознание, его уровни и формы, включая правосознание, правовую психологию и правовую идеологию. При этом не устанавливается достаточно четких взаимосвязей между каждым из указанных факторов и содержанием уголовной политики.

Между тем очевидно, что утрата идеологического, экономического и политического содержания социалистического права привела к кардинальным изменениям. Переоценка экономических основ жизни общества повлекла декриминализацию предпринимательства и спекуляции, одновременно обозначив необходимость криминализации некоторых новых проявлений экономической жизни, которая, в свою очередь, должна учитывать и политические, и социальные факторы. Как справедливо отмечается в литературе, бессмысленно и даже вредно вводить уголовно-правовые запреты тогда, когда нарушения закона легко предупредить либо когда административное наказание и механизм рассмотрения дела об административном правонарушении обеспечивают условия возмещения причиненного таким поведением вреда и низкую вероятность рецидива. Наконец, всякая криминализация экономического поведения теряет смысл, если оно уже стало настолько массовым, что введение уголовно-правового запрета изначально предопределяет избирательность, а значит, и несправедливость уголовного преследования [6. С. 41-47]. Требует научной оценки очевидный конфликт общественного сознания и международных принципов и норм по вопросу назначения наказания. Заслуживают внимания и особенности построения отношений общества с правоохранительными органами, критерии оценки деятельности которых претерпели существенные изменения.

Явно недостаточное внимание теории факторов уделяется и в цивилистике, где до сих пор отсутствуют полноценные исследования, посвященные методологической роли принципа детерминизма. Отсюда неоднозначная оценка его значения и целей использования. Иногда он рассматривается как принцип познания закономерностей формирования и развития гражданского права, который позволит найти научно обоснованный ответ на вопрос о пра- 
вовой сущности гражданского права, о внутренней структурированности отрасли, ценности каждого элемента структуры, а также проанализировать зависимости системы гражданского права и системы гражданского законодательства от внутренних и внешних системообразующих факторов [7. С. 32]. Некоторые авторы ценность такого подхода усматривают в возможности предвидения дальнейшего развития соответствующей отрасли [8. С. 299].

Применительно к гражданскому праву предлагается выделять внешние и внутренние детерминанты, однако их полноценной системы в науке гражданского права не представлено. Достаточно традиционно к первым относят экономику, однако, по мнению В.В. Васильева, взаимодействие экономики и права «является зависимым производным от фактора личности как важнейшего внешнего фактора детерминации в гражданском праве» [7. С. 33]. Как представляется, в данном случае он допускает подмену понятий, поскольку оценка личности как высшей ценности не может быть самостоятельным фактором развития права, характеризуя лишь определенный тип правовой идеологии, являющейся одним из факторов духовного порядка. Впрочем, ряд авторов вообще ограничиваются постановкой проблемных вопросов, которые, по их мнению, могли быть решены с позиций факторного подхода.

Таким образом, в современной юридической науке не сформировалось единой концепции, позволяющей использовать факторный подход в качестве методологической основы правовых исследований. Осознавая значимость выявления факторов развития права, большинство специалистов акцентируют внимание лишь на тех, которые видятся им наиболее значимыми для решения конкретной проблемы. Представляется возможным использование общефилософских начал факторного подхода для оценки правовых явлений и процессов, позволяющих, на наш взгляд, обеспечить системный характер любого правового исследования в данном направлении.

\section{Лuтература}

1. Овчинников В.И. Принцип детерминизма в методологии правоведения // Правоведение. 1984. № 2.

2. Нашии А. Правотворчество. Теория и законодательная техника. М.: Прогресс, 1974. $256 \mathrm{c}$.

3. Беспрозванный Д.Б. Типы детерминации правовых предписаний // Бизнес в законе. 2011. № 2 .

4. Тер-Акопов А.А. Преступление и проблемы нефизической причинности в уголовном праве. М.: ЮРКНИГА, 2003. 480 с.

5. Гревцов $O . B$. Уголовная политика современной России и предупреждение преступности: дис. ... канд. юрид. наук. СПб., 2000. 182 с.

6. Максимов С.В., Недогонова М.А. Проблемы и перспективы криминализации нарушений антимонопольного законодательства в России // Законы России: опыт, анализ, практика. 2014. № 2 .

7. Васильев B.B. Философско-правовая сущность детерминации в цивилистике: постановка проблемы // Вестник ТвГУ. Сер. «Право». 2014. № 3.

8. Мигачева А.Ю. О необходимости исследования принципа детерминизма в связи с развитием методологии гражданского правоведения // Теория и практика общественного развития. 2009. № 3-4. 
Grushin Feodor V. Academy of the Federal Penitentiary Service of Russia (Ryazan, Russian Federation). DOI 10.17223/22253513/16/4.

\section{A FACTORIAL APPROACH IN BRANCH LEGAL SCIENCES}

Key words: factorial approach, essence of law, system of law, law making, determining factors, effectiveness of law making.

One of the actual issues both in the theory of law and in branch legal sciences is the analysis of the reasons and conditions determining the development and functioning of the system of law. Applying a factorial approach to the evaluation of legal phenomena, we can reveal the essence of law; increase the effectiveness of both law-making activities and realization of legal rules. A factorial approach is being widely analyzed in philosophical works and the works on common theory of law. However, we come across the ideas of determinism in branch legal sciences more often since the research into the system of the branch of law on the basis of these methodological grounds promotes the cognition of its inner content, its structural elements, their interrelationship and interdependence, inner contradictions and, consequently, creates the conditions for the effective modernization of a separate branch of law.

We cannot but notice a principally different approach to the determination of purposes for the application of a factorial theory in branch sciences. A.A.Ter-Akopov thought that "it's no use speaking about sociology, criminal law and criminal policy beyond the category of determinism". It was O.V.Grevtsov who realized a factorial approach in legal science among the first and separated both objective and subjective factors of the formation of criminal policy (the factors of criminality). According to him: "the factors determining criminality and criminal policy represent a dialectical unity of objective conditions and subjective prerequisites for the social development and include political, legal and other public relations, natural conditions and legal culture".

Civil law pays little attention to the theory of factors; no research connected with the methodological role of the principle of determinism has been carried out yet. This results in an ambiguous evaluation of its significance and purposes for its application. Civil law is supposed to separate both external and internal determinants. Economics can be referred to the former ones but V.V.Vasiliev believes the collaboration of economics and law "to be a dependent derivative from the factor of a personality as an important external factor of determination in civil law".

Thus, modern legal science does not know any unified concept enabling us to apply a factorial approach as a methodological basis for legal research.

\section{References}

1. Ovchinnikov, V.I. (1984) Printsip determinizma v metodologii pravovedeniya [The principle of determinism in the methodology of jurisprudence]. Pravovedenie. 2. pp. 35-39.

2. Nashits, A. (1974) Pravotvorchestvo. Teoriya i zakonodatel'naya tekhnika [Theory and legislative technique]. Translated from Romanian by I. Fodor. Moscow: Progress.

3. Besprozvannyy, D.B. (2011) Types of the determination of the legal orders. Biznes v zakoneBusiness in law. 2. (In Russian).

4. Ter-Akopov, A.A. (2003) Prestuplenie i problemy nefizicheskoy prichinnosti v ugolovnom prave [Crime and non-physical problems of causality in criminal law]. Moscow: YuRKNIGA.

5. Grevtsov, O.V. (2000) Ugolovnaya politika sovremennoy Rossii i preduprezhdenie prestupnosti [Criminal policy of modern Russia and crime prevention]. Law Cand. Diss. St. Petersburg.

6. Maksimov, S.V. \& Nedogonova, M.A. (2014) Problems and Perspectives of Criminalizing Breaches of Anti-Trust Legislation in Russia. Zakony Rossii: opyt, analiz, praktik. 2. (In Russian). 
7. Vasiliev, V.V. (2014) Philosophical and legal essence of the principle of determinism in civil law: Problem. Vestnik TvGU. Ser. "Pravo" - Herald of Tver State University. Series: Law. 3. pp. 3037.

8. Migacheva, A.Yu. (2009) About the need principle of determinism in connection with development of civil law methodology. Teoriya i praktika obshchestvennogo razvitiya - Theory and Practice of Social Development. 3-4. (In Russian). 